\title{
Realisation of Parameters of Bologna Process at Teaching of Philologists in the Republic of Kazakhstan
}

\author{
Zhaidarkul Belassarova $^{1}$, Nurbek Muratbek ${ }^{1}$, Indira Sultaniyazova ${ }^{1}$, Aida Nurbaeva ${ }^{1} \&$ Dina Sabirova $^{1}$ \\ ${ }^{1}$ Kazakh Abai National Pedagogical University, Almaty, Kazakhstan \\ Correspondence: Aida Nurbaeva, Raiymbek street, house 245 g, Apartment 7, Almaty, Kazakhstan. Tel: \\ 8-702-548-8835. E-mail: dinasabirova_84.kz@mail.ru
}

Received: March 19, 2015 Accepted: April 21, $2015 \quad$ Online Published: May 14, 2015

doi:10.5539/res.v7n7p356 URL: http://dx.doi.org/10.5539/res.v7n7p356

\begin{abstract}
Modern education is a fundamental basis of human life which acts as integral, resumptive value of spiritual culture. Together with political and legal culture, education forms aesthetic and moral personality feature in indissociability with society's life. The problem of teaching of philological disciplines students in the course of realisation of Bologna process parameters is considered in this article. The conceptual approach to development of education system in Kazakhstan is defined by the strategy of its re-organization during the reformation of the whole education system. In the course of research, the authors have represented the main points of implementation of Bologna process in higher education system and its influence on teaching of philologists. Typical curricula of philological disciplines have been analysed, the Working curricula of the leading state and private universities with philological disciplines have been compared. Strengths and weaknesses of this process have been revealed. The practical recommendations for improvement of realisation of Bologna process parameters at teaching of philologists in the Republic of Kazakhstan have been proposed. The purpose of functioning of education social institute in a society is formation of intellectual and moral potential of the nation. Efficiency of the education social institute functioning should be studied using complex approach which takes in account the variety of heterogeneous subjects of education and the system of their interconnections and management. The authors have come to conclusion that the state should develop system of measures in order to save accumulated experience of philologists teaching organisation, the state should find the balance between theory and practice when teaching the student, as well as to invent a system for improvement of professional skill throughout the whole period of working activity, to create centers and national registers of philologists specification.
\end{abstract}

Keywords: Bologna process, teaching of philologists-students, literary studies, historical grammar, comparative lexicology, lexicography

\section{Introduction}

Unification of the higher school in the European countries was about to happen long ago, in the middle of XX century, because of the fact it became non competitive in comparison with American education. Attempts for improvement of the European education according to uniform standards were begun in 1957 by signing of the Roman agreement which contained essentially new problems: bringing national legislations in the education sphere in accordance with the all-European standards, greater access to higher education, increase of academic mobility of students and demand for them on a labour market, creation of long-term teaching systems.

Eventually these ideas were developed in resolution of conferences of Education Ministers of the European countries (1971, 1976), in the Maastricht contract (1992). Further various programs were implemented under the aegis of EU and the Council of Europe.

The history of Bologna process can be divided in three stages:

background: from the Great Charter of Universities (1988) to the Bologna declaration; beginning: the Bologna declaration (1999); development: after the Bologna declaration (Baidenko, 2004).

Ideas of creation of the European university community and the uniform European environment of higher education came from the Bologna University which is the oldest Italian and European university. In 1986 while preparing for the 900th anniversary the university management has proposed all universities of Europe to accept 
the Great Charter of Universities-Magna Charta Universitarum. This idea was picked up enthusiastically, and the chancellor of 80 high schools signed this document proclaiming uniform and timeless values of university education, as well as necessity of close connection between them, during anniversary celebrations in 1988 (Baidenko, 2002).

For the present 40 countries take part in a so-called Bologna process which should come to the end by 2010 .

Bologna process is a process of creation of uniform European environment of higher education. It is a blow of integration trends which are being actively developed in these countries recently. The Europe feels itself more and more as the unitary whole: the general economic space was created, borders have been opened, the common currency was introduced, the all-European labour market is being formed. In such conditions, diversity of higher education systems and incomparability of qualifications impede mobility of skilled labour.

The official date of Bologna process is June, 19th, 1999 when Ministers of Education of 29 European states have accepted the declaration "Zone of the European higher education" or the Bologna declaration, in Bologna at a special conference. Bologna process is open for membership of other countries. The further intergovernmental meetings took place in Prague (2001), Berlin (2003), Bergen (2005) and London (2007). Now Bologna process unites 46 countries. It is supposed that its main aims should be attained by 2010. Russia has joined Bologna process in September, 2003 at the Berlin meeting of Ministers of Education of the European countries. Many high schools of Russia are involved in implementation of the basic directions of Bologna process.

Obligations of participants: Countries join the Bologna Declaration on a voluntary basis (Dobrynin, 2006). The countries join Bologna process on a voluntary basis by signing of the corresponding declaration. Thus they undertake certain obligations, some of which are limited by terms:

To start issuing the European official transcripts of the uniform form to bachelor and master degrees, free of charge, for all graduates of high schools of the countries which participate in Bologna process since 2005;

To reform national education systems according to the main provisions of the Bologna declaration by 2010 .

The purpose of the Bologna declaration is establishment of the European environment of higher education, as well as mainstreaming of the European system of higher education globally.

One of the important provisions of Bologna process is orientation of higher educational institutions to the end result: the skills of graduates should be applicable and used for the benefit of people of his/her country, and other countries of Europe. The academic degrees and other qualifications should be on demand on the European labour market; the professional acknowledgement of qualifications should be simplified and facilitated. Official transcripts to diploma, recommended by UNESCO, are planned to be used everywhere for acknowledgement of the qualifications issued by a certain high school (Kasevich, Svetlov, Petrov, \& Tsyb, 2004).

The accurate unification of student's documents confirming level and quality of learned skills for comparison of higher education in different countries. These measures should provide employment of the European citizens with higher education and the international competitiveness of the European higher education.

Many theorists consider Bologna process to be a symmetric European answer to the phenomenon of globalisation (Baidenko, Dobrynin, \& Shadrikov)

The other group of scientists considers these tendencies in line with bringing the domestic education to the European dimension (Balykhina, Bermus, \& Mukhametkaliev).

Marik K. Van der Vendev in his turn affirms that the European education is facing a threat which comes from the nonconventional and non-European providers of higher education, penetrating the European market through branches of campuses, virtual and other organisations.

The issue of organization of education which on the one side should keep the idea of national polyidentity of Europe, and on the other side should promote realisation of idea of maximum efficiency of all educational efforts in order to create conditions for self-realisation of students in the conditions of increasing competition on the labour and capital markets become urgent within the matter of Bologna reforms. The question of two-level system of higher education — basic and postgraduate (bachelor and master degrees) — is highly publicized among domestic scientists. The first level lasts not less than three years. The second level should lead to getting degree of master or doctor. Superfluous list of specialities and qualifications became a big problem in many countries. Scientists of Kazakhstan are worried about economic part of the question. Pak, Imanov, Pak, assert that the opening of each educational program is connected with a number of expenses and depends on a set of factors: contingent of students in this speciality, teaching and methodical materials, skill level of teaching staff, material and technical equipment (Pak, Imanov, \& Pak,). 
The question of establishment of Typical curricula has got a wide response. This decision actualizes accelerated introduction of professional standards with necessary qualification profile of an expert in a form of competences, coordinated with the National framework of qualifications (Pak \& Gazaliev, 2012). Now it is important to direct intellectual resources to qualitative updating of education essence, instead of to creation of management and bureaucratic structures (Pak, Shilnikova, \& Pak, 2012).

\section{Methods}

The methodology of multipronged approaches to the analysis on the basis of the following research methods: comparative, structural and analytical was used during research of realisations of Bologna process parameters at teaching of philologists in the Republic of Kazakhstan. Axiological and cultural approaches to the analysis of teaching of philologists in the Republic of Kazakhstan were implemented as well.

\subsection{Analzsis of ECTS Introduction}

Establishment of credit system according to the European credit-transfer system (ECTS). Credits mean standard units which are used for defining a volume of education. Each such unit means a set of learned concepts, connections between the concepts, accumulated skills, that is the general labour input of accumulated knowledge and skills including independent work of students and passing of intermediate and final tests, other kinds of study. The European bachelor degree requires 180-240 hours of credits, the master degrees-60-120 hours in addition. Some countries have the following requirements for charging of credits: the academic load should include $50 \%$ and more independent work of a student. The system of accumulated credits makes it possible for a student to enter university in one country, and to graduate it in another country; to change university or selected speciality during studying; to finish studying at any stage after receiving bachelor master degree, and to continue education at any convenient time.

Academic credit is a unit of labour input of educational work of a student.

30 academic credits are charged for one semester.

60 academic credits are charged for one academic year.

Bachelor degree requires at least 180 credits (three years of studying) or at least 240 credits (four years of studying).

As a rule, for a master degree student should have not less than 300 credits in total (five years of studying).

The quantity of credits for a subject cannot be fractional (on an exceptional basis it is allowed to charge 0,5 credits), since addition of credits of one semester should make 30 in total.

Credits are charged after successful passing (positive mark) of final test at a subject (examination, test, etc.).

The quantity of charged credits on a subject does not depend on mark.

Attendance of classroom-based exercises by a student is considered at discretion of high school, but does not guarantee charge of credits.

Classroom load ("contact hours" according to the European terminology), independent work of a student, abstracts, essays, course and degree works, writing of master doctor theses, practice, training course, preparation for exams, passing of exams, etc.) is included in labour input by charging of credits.

The balance between classroom hours and hours of independent work is not centrally regulated.

The uniform European six-marks estimation system is recommended:

A - "excellent" (10 percents of students).

B- "very good" (25 percents of students).

C- "good" (30 percents of students).

D-“adequate" (25 percents of students).

E-“marginal" (10 percents of students).

F (FX) - “inadequate".

Introduction of ECTS - the European system of recharge of credits is one of most technically and substantially difficult tasks within Bologna process. Credits reflect the volume of work required for completing each course in relation to the total amount of work required for a full academic year program at university, including lectures, seminars, practice, independent work, exams and tests. In order to participate in system universities prepare annually updated information packages with full description of courses, their content, requirements for training, 
grade systems, training techniques, structure of chairs of studying. Besides, the information should include the full curriculum for a certain education degree, general information about university, infrastructure, administrative procedures for registration in a program and academic calendar. The information package should be composed on native language and one of foreign languages, and should be distributed at all partner universities.

\subsection{Review of Development of Mobility at Introduction of Bologna Process Parameters}

For comprehension and assertion of competitiveness of own knowledge and skills, each student should have a possibility to study and train abroad at least for a short time period. This allows to reduce quantity of hours for studying of foreign languages at the basic high school. Committed preparation for passing of language tests of TOEFL type, tests for entering GRE economy magistracy, GMAT management, etc. promote mobility of students.

In particular, the academic mobility presupposes the following:

1) The student should study at foreign high school for semester or academic year.

2) The student should study in language of host country or in English; he/she should pass current and final tests in the same languages.

3) Training abroad by mobility programs is free of charge for a student-accepting high school does not charge money for studying.

4) The student pays for: trip, residing, food, medical services, studies beyond the coordinated (standard) program (for example, studying of language of host country).

5) The received credits are charged for a student at the home high school (which a student has entered), if studying is agreed with dean's office; the student does not have to pass any additional subjects during studying abroad.

6) The high school has a right not to charge academic credits received by a student in another high schools, other than those, agreed with dean's office.

7) Getting of combined and double diplomas by a student is encouraged.

8) Bringing higher education in different countries to uniform standards. It concerns development of similar curricula, trainings, researches.

Introduction of a concept of continuous (lifelong) studying which allows the person to get several diplomas and scientific degrees during life, and allows the university to improve financial and material support considerably at the expense of providing information and material resources for persons willing to continue studying. The idea of LLL (Life Long Learning), education proportional to the whole life underlies this concept.

\section{Results}

\subsection{Analysis of the Kazakhstan Educational Programs of Philological Profile}

6 primary goals which promote unification of Europe in a sphere of education were specified in Bologna declaration (Shadrikov, 2004).

Priority of education is emphasized in the Concept of state policy in education sphere which defines strategic milestones of reformation of education in Kazakhstan. The Concept lists the previous negative facts about the Kazakhstan education system: "closedness and irresponsiveness of system to the world experience; technical and technological backwardness; lack of due methodological and methodical support; aiming at getting already existing knowledge (Koshanov, 2006). It is commonly known that the Republic of Kazakhstan is the first Central Asian country which has honoured to join Bologna declaration and became a full member of the European educational environment (Concept of academic mobility of students of higher educational institutions of the Republic of Kazakhstan, 2007).

The aims of Bologna declaration are creation of uniform, all-European labour market for top-qualification workers, providing an easy access to the European education, support of comparable system of higher education levels (Kenshinbai , 2009).

One of the key purposes of Bologna declaration is creation of generalised model of the international higher education by introduction of two levels, i.e. the system based on two basis cycles: pre-degree and post-degree.

The Kazakhstan educational programs aspire to correspond to the European standards: three-level system (baccalaureate - master programme - doctoral programme), elective subjects, system of credits (ECTS), grade-rating system were introduced. The academic mobility was declared, and it was attempted to get financial 
support for it.

All these recommendations of Bologna declaration are acceptable and necessary for the Kazakhstan education system, and they are implemented in the country, though to different extents (Mukhametkaliev, 2001).

Let's consider obligatory parameters of Bologna process and estimate their realisation in Kazakhstan (Table 1).

Table 1. Comparative analysis for comparability of Bologna process parameters

\begin{tabular}{lll}
\hline Criteria & Requirement of Bologna process & $\begin{array}{l}\text { Realization of Bologna process in } \\
\text { Kazakhstan }\end{array}$
\end{tabular}

\begin{tabular}{llll}
\hline $\begin{array}{l}\text { Levels of higher education Three-level system of higher } \\
\text { system }\end{array}$ & $\begin{array}{l}\text { Three-level education system } \\
\text { education; }\end{array}$ & & $\begin{array}{l}\text { successfully introduced (baccalaureate } \\
\text { programme-doctoral }\end{array}$ \\
& & programme)
\end{tabular}

Period of the first cycle of At least 3 years studying

System of test units

Academic credits ECTS

Academic mobility

Of students

Of teaching staff

Of high school management

European official transcript European official transcript

Control of quality of higher Control of quality of higher education education.

Flexibility of educational Presence elective disciplines programs

Research environment

Creation of uniform European research environment.
At the present, the first cycle of studying in Kazakhstan lasts 4 years

The credit settlement system is accepted at all high schools of the country.

Many high schools of the country change credit settlement system to system of test units in ECTS

Mobility inside the country is being actively practised. Realisation of academic mobility by means of self-financing is welcomed

Is at development stage.

Is being actively practiced.

Is implemented at all high schools of Kazakhstan.

Is successfully implemented and practised.

Is implemented at all high schools of Kazakhstan

Projects for enter the uniform European research environment are being developed.

From the table we see that Bologna process is being consistently implemented in the republic.

After introduction of the State general educational standard (further SGES) in 2010, the high schools got an opportunity to provide elective courses for students. The analysis of Typical curricula of philological specialities 
of bachelor programme showed that more than $70 \%$ of the total 154 credits are dedicated to elective courses (Table 2).

Table 2. Analysis of Typical curricula of philological specialities

\begin{tabular}{|c|c|c|c|c|c|c|c|c|c|}
\hline Disciplines & $\begin{array}{l}\text { General } \\
\text { subjects }\end{array}$ & $\begin{array}{l}\text { Obligatory } \\
\text { component }\end{array}$ & $\begin{array}{l}\text { Optional } \\
\text { component }\end{array}$ & $\begin{array}{l}\text { General } \\
\text { subjects }\end{array}$ & $\begin{array}{l}\text { Obligatory } \\
\text { component }\end{array}$ & $\begin{array}{l}\text { Optional } \\
\text { component }\end{array}$ & $\begin{array}{l}\text { Main } \\
\text { subjects }\end{array}$ & $\begin{array}{l}\text { Obligatory } \\
\text { component }\end{array}$ & $\begin{array}{l}\text { Optional } \\
\text { component }\end{array}$ \\
\hline $\begin{array}{l}\text { Number of } \\
\text { credits }\end{array}$ & 33 & 33 & & 64 & 20 & 44 & 32 & 5 & 27 \\
\hline
\end{tabular}

Obligatory optional courses in Kazakhstan relate to subjects connected with development of common cultural competences. The student has to choose, study and pass several subjects of this sphere. Elective courses are limited by student's specialisation. The student has to select these courses according to a certain quantity of credits. Additional variation courses are divided into obligatory (provided by SGES) and optional subjects. Individual curricula of students where students introduce the selected subjects in the individual plan by advice are provided.

On the average optional subjects make about $60-70 \%$ from the general number of subjects, thus their number grows each studying year, so on a last year of bachelor programme they can make a significant part of educational program.

On the 1 and the 2 year of bachelor programme of philological specialities obligatory subjects make-70\%, and on the 3-4 years-30\%.

\subsection{Analysis of the Kazakhstan Curricula of Philological Specialities}

Teaching of philologists is proposed by various higher educational institutions-National universities, pedagogical universities, academies and institutes. However the operating state standards of philologist teaching differ in content of the above mentioned blocks. This applies both to content and scope of subjects with the same name, requirements to quality of teaching. Moreover, actually there are differences at the level of conceptual basis of certain subject including its content (conceptual basis). Currently, a topical problem is treating fundamental knowledge as fixed knowledge or on the contrary as developing knowledge; as academic knowledge or on the contrary as knowledge capable to be transformed to methods of work with it. However a key problem is not limited to the mentioned differences. The problem is common for all high schools teaching philologists, and consists, in my opinion, in the following: how to teach a student capable to professional activities in conditions of developing practical activities (research, teaching, translational, communication, editorial activities, etc.). Of course high schools have accumulated a certain experience for solving of this problem. At classical universities this experience includes introduction of subject which content consists in studying of: trends of development of language, literature, folklore, communications - the basic subjects of philology, as well as the basic subjects of professional activity of a philologist (history of teaching of Russian/literature; tendencies of mass communication language development; modern literary process; general and professional rhetoric; modern communications, etc.); studying of professional activity methods (language, literature teaching methodology; eloquence teaching methodology; introduction to scientific philological research and so forth); introduction of applied subjects (philological support of records management/journalism/public relations/information and publishing activities/study of art/modern communications, etc.) with inclusion of work practice. One more point should be noted. The sense and aim of higher philological education is now not providing a person with system of knowledge and skills, but teaching a philologically competent person, i.e. a person which is competent in a certain sphere and is master of a subject, that is which is capable to reign it (to study it, to transform it to other subjects and knowledge, to promote its development / to brake development, to speak freely about a subject).

The analysis of philological specialities' curricula has shown that elective subjects are fixed at a certain part of curriculum. This means that in a certain semester or studying year the student has to choose one from two or three proposed subject which should be studied and passed in this semester according to curriculum. The student cannot postpone it to another semester. The other part of a question becomes more and more topical for philological specialities. A certain quantity students trained of foreign philology do not have a choice at all, because if some subject will be chosen by a very small number of students (less than five), it will not be taught, and the students will have to choose another subject. At the same time, application of a principle of lower limit 
of student groups and a principle of filling the remaining groups can result and results in absence of personal choice of students from small groups which form the majority of Russian and foreign philology. For example no from the proposed subjects has got five bachelor-students. In this case the dean's office has a right to redistribute students according to majority principle.

This is not the only one problem at choosing elective subjects by philologists-students. Currently the main problem which is faced by each literary professor is unwillingness of students to read literary texts. This unwillingness is formed already at school. The pupils have no habit to reading, no interest to cognition through reading belletristic literature. Thus, the volume of read literary texts before entering a high school is almost at zero level [Kozhevnikova,2010].

This issue is common almost for all philological specialities supposing studying of literature: philology, literary studies, the Kazakh language and literature, Russian language and literature.

As a result the language subjects reveal over literary studies subjects which affects the general level of knowledge of philologists-students as well. At the same time, the schools of Kazakhstan do not cultivate interest to historical grammar, comparative lexicology, root theory, lexicography and colloquial vocabulary.

\section{Discussion}

Professor's work in Kazakhstan is organised according to plans. Each professor gets an academic load in academic hours at the beginning of the year (that is the quantity of lectures, exams, etc.). The load corresponds to the loan - to the volume of work for which a fixed salary is paid. Thus the professor gets guaranteed and stable salary, and the high school management draws up and distributes classroom-based fund (Kozlov, 1999).

Far not all constants of credit system are easily implemented in practice. Attempts to democratize the process of passing of examinations lead to domination of test tasks which are checked by matrix or computer method. This practice deprives philologists-students of possibility to fully analyze literary reads (Krivoshapova, 2009).

It is time for our higher school to reject intermediate and final assessment of students solely by testing method which is based on a very simplified "crossword" system with "yes" or "no" answers to elementary questions which do not reflect the essences of studying material and do not cultivate active cogitative activity and willingness to read recommended literature at students. Real knowledge and intellectual abilities of a person can be revealed only by combined examinations (written and spoken answers) reflecting skills of grammatical writing, level of rhetoric and abilities to think abstractly (Kasevich, Svetlov, Petrov, \& Tsyb, 2004).

Positive results of reformation of education system:

- Bachelors are supposed to form the majority of workers, and masters - the intellectual elite. Teaching of bachelors is directed to a wide area of professional work, teaching of masters - to mastering single-discipline knowledge and features of specific professions. The bachelor programme will respond to the increased demand for higher education;

- Bologna system makes it possible to combine knowledge: it is possible to become a bachelor of one speciality, and to complete master course of another speciality. The inconvenient and expensive system of paid second higher education which is being practiced currently will disappear;

- The two-level education system suits well for modern life, since accumulated knowledge tend to become outdated very quickly. The new education system supposes "lifelong" education consisting in programs of post-graduate education for graduates;

- The academic mobility provides great possibilities and advantages in acquisition of knowledge in other high schools, especially abroad. A diplomate will be in demand in the international labour market (Sarsembaeva \& Kaigorodtsev).

First of all, the described situation, presupposes that education environment of philologists teaching should be uniform - as the fact of the present and/or as the desired fact of the future. Secondly, this situation shows community of problems existing in this environment.

Positive results sustain a right direction of introduced reforms. Module-credit system of studying was introduced in order to implement the main parameters of Bologna process, and is now applied at each of three educational levels of teaching at philological specialities: bachelor programme-master programme-post-graduate programme $(\mathrm{PhD})$.

\section{Conclusion}

The credit education technology ensures international acknowledgment of national educational curriculums, 
academic mobility of the students, professors and continuity of all stages of education; promotes improvement of education quality. The program of academic mobility is operating.

Synthesis of Bologna recommendations and traditional education systems allows to speak about the National education system.

In the recent years, domestic and European philological education exist in the new conditions defined by Bologna agreement which provides introduction of two-level education system (bachelor programme-master programme); introduction of modular system of education; simplification of diplomas acknowledgement; introduction of test units (credits) system; ensuring cooperation in the sphere of quality support; realisation of mobility of professors and students, etc. the Plan of reorganisation of the higher pedagogical education including philological one caused a wide response and ambiguous opinions in the academic circles of the different countries.

Now reorganisation of bases of philological education is happening not only in the Kazakhstan high schools, but also in the theory and practice of education of other countries. Constant increase in speed of information turnover in a society, activity of mass-media, fast updating of socially-humanitarian and scientific and theoretical knowledge place new demands on a philologist. A highly skilled professor-philologist should have theoretical, practical, psychological, pedagogical, research readiness for intellectual and creative professional and self-educational activity (Balykhina, 2003). The modern society forms new values for teaching of future teachers of native and foreign languages: a graduate should be ready to interaction with other people during transmission of culture, exchange of information, of ways of activity, of self-realisation experience. The philologist of a new generation works in wide sphere of "person - society—person", that is why criteria of readiness for professional activity, methods, forms, means of teaching change; necessity of continuous practice increases in the face of constant theoretical education, thus each professor-philologist incurs responsibility for self-education and professional improvement (Sadovnichy, 2006).

Since countries-participants of Bologna process aim to create a uniform European educational environment, we think that the key documents, that is competence standards for sciences of philological cycle and methodologies of their teaching should be developed and accepted with all countries. It is necessary to create international initiative groups consisting of scientists and practitioners. Realisation of the general competence standard on the base of the international experience and taking into account necessary adaptation to traditions and requirements of specific country will allow to provide qualitative philological education and competitiveness of graduates on the European labour market. During studying in a high school students of philological specialities study special sciences, their methodologies and sciences of psychological and pedagogical sphere. Introduction of modular system in the Kazakhstan high schools result in the following difficulties: improper qualification of staff, lack of developed modular programs, incompatibility of modular system with existing system of teaching of professors-philologists, lack of specially trained tutors (advisers for drawing up of individual curricula), etc..

Solving of these problems can be provided by teaching a qualified personnel for the further work in a native high school (academic staff, tutors-advisers), development of original educational programs in philological sphere within the limits of interdisciplinary bachelor programmes, master programmes and postgraduate studies by each university, creation of a database of scientific literature, regular scientific and practical conferences on topical problems of philology, improvement of technical support of philological departments, etc. Both domestic and foreign professors admit that practice is very important in teaching of philologists in a high school. The modern pedagogical education should be practically and methodically-oriented (Problems of standardization of the higher pedagogical education, 2001). In Kazakhstan bachelors-philologists have their first continuous pedagogic practice at schools, thus the practice is rather passive; the second practice - as teachers. On master programme students participate in teaching and research activity at a high school. There is a contradiction between theory and practice in philological education. On the one hand, currently we can observe complication of functions (educational, developing, diagnostic and research) and intensification of practice content. Both domestic and foreign scientists doubt that practical/oriented education of a philologist-bachelor will be adequately apprehended by employers (Bermus, 2005). Therefore the Republic of Kazakhstan should develop a measuring system for preservation of accumulated experience of professor's teaching organisation, should find an optimal balance between theory and practice at teaching of students, and to think over a system of professional skill improvement throughout the whole period of working activity, to create centers and national registers of specification of philologists.

Implementation of all points of the agreement and achievement of notable results require many years of researches and planning. The process of modernisation of the higher philological education system is a 
fundamental part of society's development, since philological education is a key resource for increasing of intellectual, spiritual and moral potential of any nation, and ht nation's future depends on its dynamical development.

\section{References}

Baidenko, V. I. (2002). Bologna process: Incremental dynamics and variety (p. 409). M.

Baidenko, V. I. (2004). Bologna process. Series of lectures (p. 208). Logos, M.

Balykhina, T. M. (2003). The structure and content of the professional competence of Teachers (methodological problems of teaching the Russian language) (p. 476).

Bermus, A. G. (2005). The Russian teacher education in the context of the Bologna Process. Pedagogics, 2005(10), 102-109.

Dobrynin, M. A. (2006). Bologna declaration as formation factor for European education environment. Pedagogics, 9, 103-108.

Kasevich, V. B., Svetlov, R. V., Petrov, A. V., \& Tsyb, A. A. (2004). Bologna process in questions and answer (p. 108). St. Petersburg. Un-ta.

Kenshinbai, T. I. (2009). Reformation of higher education in Kazakhstan and Bologna process: Information material for practical deeds. Bologna process:Essence and prospects of development (pp. 7-27).

Koshanov, A. (2009).National economic interests and ownership relations (p. 535). Almaty: Eksklyusiv.

Kozhevnikova, S. N. (2010). Problems of teaching of the foreign literature at journalism branch. The foreign literature at high school: Innovations, techniques, teaching and studying problems (pp. 69-72). Yekaterinburg.

Kozlov, V. N. (1999). Transfer of technologies as a principle of high intellectualization of educational and scientific processes. Modern technologies of teaching: Materials of the 5th international conference. St. Petersburg: SPbETU.

Krivoshapova, T. V. (2009). Information and analytical center-Expert assessment-Bologna process in Kazakhstan and Russia: Parallel and paradoxes. Retrieve from http://www.ia-centr.ru/expert/3956/

Mukhametkaliev, T. M. (2011). Bologna process in Kazakhstan: Objective opinion Modern education, 1(81), 20-24.

Pak, Y. N., \& Gazaliev, A. M. (2012). Bologna process and Kazakh realia (p. 417). Karaganda: KarGTU.

Pak, Y. N., \& Imanov, M. O., \& Pak, D. Y. (2013). Vectors of modernisation of the higher technical school of Kazakhstan in a context of Bologna process. International magazine of experimental education (Vol. 10, pp. 36-41).

Pak, Y. N., Shilnikova, I. O., \& Pak, D. Y. (2012). Professional standard as practical and focused approach to formation of educational programs of the higher education. Proceedings of KarGTU (Vol. 4).

Bermus, A. G., \& Kutjev, V. O. (2001). Problems of standardization of the higher pedagogical education: "Round table". Pedagogics, 6, 52-66.

Sadovnichy, V. A. (2006). Higher education today, 6, 5-9.

Sarsembaeva, G. Zh., \& Kaigorodtsev, A. A. (2014). Kazakhstan in Bologna process. Retrieved from http://old.group-global.org/

Shadrikov, V. D. (2004). State educational standards of the higher vocational education and Bologna process. Educational questions, 4, 5-9.

\section{Copyrights}

Copyright for this article is retained by the author(s), with first publication rights granted to the journal.

This is an open-access article distributed under the terms and conditions of the Creative Commons Attribution license (http://creativecommons.org/licenses/by/3.0/). 